\title{
Metals, trace elements and ecotoxicity in sediments of the Cubatão River, Brazil
}

\author{
Borrely, S.I. ${ }^{1}$; Garcia, V.S.G. ${ }^{1}$; Borrely, T. ${ }^{3}$ \& Favaro, D I.T. ${ }^{2}$ \\ ${ }^{1}$ Instituto de Pesquisas Energéticas e Nucleares (IPEN/CNEN, SP), Centro de Tecnologia das Radiações (CTR), \\ Av. Prof. Lineu Prestes 2242, 05508-000, SP, Brazil. \\ ${ }^{2}$ Instituto de Pesquisas Energéticas e Nucleares (IPEN/CNEN, SP), Laboratório de Análise \\ por Ativação Neutrônica (LAN/ CRPq), São Paulo, Brazil. \\ ${ }^{3}$ Instituto de Física da Universidade de São Paulo (IFUSP), Laboratório de Novos Materiais Semicondutores (LNMS).
}

Received February 16, 2018; Accept April 10, 2018

\begin{abstract}
The Cubatão River is one of the most important waterways of the coast of São Paulo. The continuous discharge of domestic and industrial effluents into the river and its tributaries resulted in loss of water quality across the system. Industrial and domestic landfills are also located around the studied area. The purpose of this study was to assess two aspects of sediments from the river and two of its tributaries (Perequê and Pilões Rivers): presence of trace elements and toxic metals, and ecotoxicity. Four sampling surveys were conducted from 2010 to 2011 on six different sites (here named P0, P2, P4, P5, P7 and P8). Ecotoxicity was assessed by exposing Hyalella azteca to the collected sediments. Instrumental Neutron Activation Analysis (INAA) and Atomic Absorption Spectrometry (GF AAS and CV AAS) techniques were applied for measuring concentration of metals and trace elements. The latter enabled quantification of $\mathrm{Cd}, \mathrm{Pb}$ and $\mathrm{Hg}$, while the former enabled quantification of a wide range of metals and trace elements. As, $\mathrm{Cr}$ and $\mathrm{Zn}$ concentrations obtained by INAA as well as AAS results were compared to threshold effect levels (TEL) and probable effect levels (PEL), the sediment quality guidelines proposed by the Canadian Council of Ministers of the Environment (CCME) for evaluating the potential effects on aquatic organisms. Cd and $\mathrm{Hg}$ values did not exceed TEL at the most of samples. Pb exceeded TEL at only one site campaign. As, $\mathrm{Cr}$ and $\mathrm{Zn}$ values exceeded TEL in most of sampling sites, with P2 and P4 showing the highest concentrations. Enrichment Factor (EF) and Geoaccumulation Index (IGeo) were calculated for the elements determined by INAA using North American Shale Composite (NASC) and regional background values. In short, $\mathrm{As}, \mathrm{Br}, \mathrm{Cr}, \mathrm{Hf}, \mathrm{Pb}, \mathrm{Sb}$ and $\mathrm{Zn}$ were the elements found in concerning amounts, especially As, $\mathrm{Br}, \mathrm{Cr}$ and $\mathrm{Zn}$. Toxicity results revealed toxic effects on sediments from P2 and P5 (mortality $>50 \%$ ). Body size analysis demonstrated negative effects at P4 (length smaller than 2,500.00 $\mu \mathrm{m}$ ). Data crossing analyses indicate As and Br as main possible contributors to high toxicity levels.
\end{abstract}

Keywords: Cubatão River, heavy metals, $H$ azteca, sediments, trace elements.

\section{INTRODUCTION}

Inorganic contaminants are considered environmental pollutants in several monitoring programs around the world. In Brazil, the main sources of metals and metalloids are related to mining, manufacturing, hydrocarbon combustion, domestic sewage, landfill and even storm water runoff flood waters (Silva et al, 2011; Terra et al, 2007). For decades, Cubatão has been the epicenter of industrial development that took place in the central portion of São Paulo Coast, with substantial negative impacts to the surrounding environment. Petrochemical refinery, metallurgy, steel, fertilizer and chemical production are among the main activities taking place in and around Cubatão, and the main pollutants released by such sources are concentrated in the Cubatão River and its tributaries. Other sources of pollution include landfills and dumping sites,

*Corresponding author: Vanessa Granadeiro; e-mail: vanessagranadeiro@gmail.com 
such as the Sitio das Neves Landfill, the Pilões Landfill and contaminated industrial sites (Ferreira Braga, 2009; CETESB, 2015). Cubatão has long been known as a polluted region; the air pollution in that locality resulted in several diseases and death (CETESB, 2015). Considering the impacts of pollutants on aquatic biota, monitoring programs should include the assessment of sediments toxicity. Ecotoxicity data is relevant for showing if the environmental quality is suitable for the diverse living organisms; this is locally important because the Cubatão River is the main source of potable water for the region. It is also relevant for the protection of aquatic life. Undesired toxicity was previously found in the waters of Cubatão, which was attributed to excessive amounts of phenol, ammonia, nitrate, metals, and biological oxygen demand (Garcia et al., 2017; CETESB, 2015).

In 1997 and 1998, metals and non-metals in surface sediments from the Santos Estuarine System (SES) were quantified. $\mathrm{Hg}$ concentrations of 0.10 up to $6.77 \mathrm{ppm}$ were detected (sediment fraction $<63 \mu \mathrm{m}$ ) at the estuarine portion of Cubatão river (Luiz-Silva et al., 2006). Cadmium, lead, copper, mercury, nickel, and zinc were also detected in the SES (Lamparelli et al., 2001; CETESB, 2015). Steel production, fertilizer, and phosphogypsum were among the industrial activities associated with radionuclide concentrations in the studied sites, particularly uranium, thorium, and hafnium (Silva et al., 2006). Moreover, these authors also detected high concentration of metals and non-metals in surface sediments, the most notorious case being high levels of mercury in Cubatão river sediments.

The objective of this paper was to determine the levels of metals and trace elements in sediments of the Cubatão River and to assess the related toxic effects to aquatic organisms. Hyalella azteca was used in sediment toxicity tests. Instrumental Neutron Activation Analysis and Atomic Absorption Spectrometry analytical techniques were applied to determine the levels of inorganic contaminants.

\section{MATERIALS AND METHODS}

\section{Description of studied area and sampling}

The Cubatão River and its basin are located roughly 58 $\mathrm{km}$ from São Paulo, in the "Baixada Santista Metropolitan Region" which comprises 9 cities, including Cubatão, and is situated on the central portion of the coast of the State of São Paulo. Cubatão and Pilões rivers supply potable water for Santos and Cubatão cities, by the use of about $3.28 \mathrm{~m}^{3}$ per second of water from the Cubatão River (CETESB, 2015).

Sediments were collected at Cubatão, Perequê and Pilões Rivers in four different periods (March and August 2010; February and June 2011). The sampled sites are indicated in Figure 1. A van Veen grab sampler was used to collect the sediments ( $2 \mathrm{~kg}$ of sediment sample for each site/campaign, approximately). Then aliquots were taken in replicates and dried at $40^{\circ} \mathrm{C}$ (ventilated oven), sieved through a $2 \mathrm{~mm}$ mesh, milled in the agate mortar and sieved again through a 200 mesh, in duplicate. For the biological assays, aliquots of sediments were preserved in plastic bags and stored under refrigeration until ecotoxicological assays $\left(4^{\circ} \mathrm{C} \pm 0.5^{\circ} \mathrm{C}\right)$.

\section{Instrumental Neutron Activation Analysis (INAA)}

For multi-elemental analysis, approximately $200 \mathrm{mg}$ of sediment (duplicate samples) and reference materials were weighed and sealed in pre-cleaned double polyethylene bags for irradiation. Single and multi-element synthetic standards were prepared by pipetting appropriate aliquots of standard solutions (SPEX CERTIPREP) onto small sheets of Whitman No.41 filter paper. Sediment samples, reference materials and synthetic standards were irradiated for 8 hours under a thermal neutron flux of $10^{12} \mathrm{~cm}^{-2} \mathrm{~s}^{-1}$, at the IEA-R1 nuclear research reactor, which is located at the IPEN. Two series of
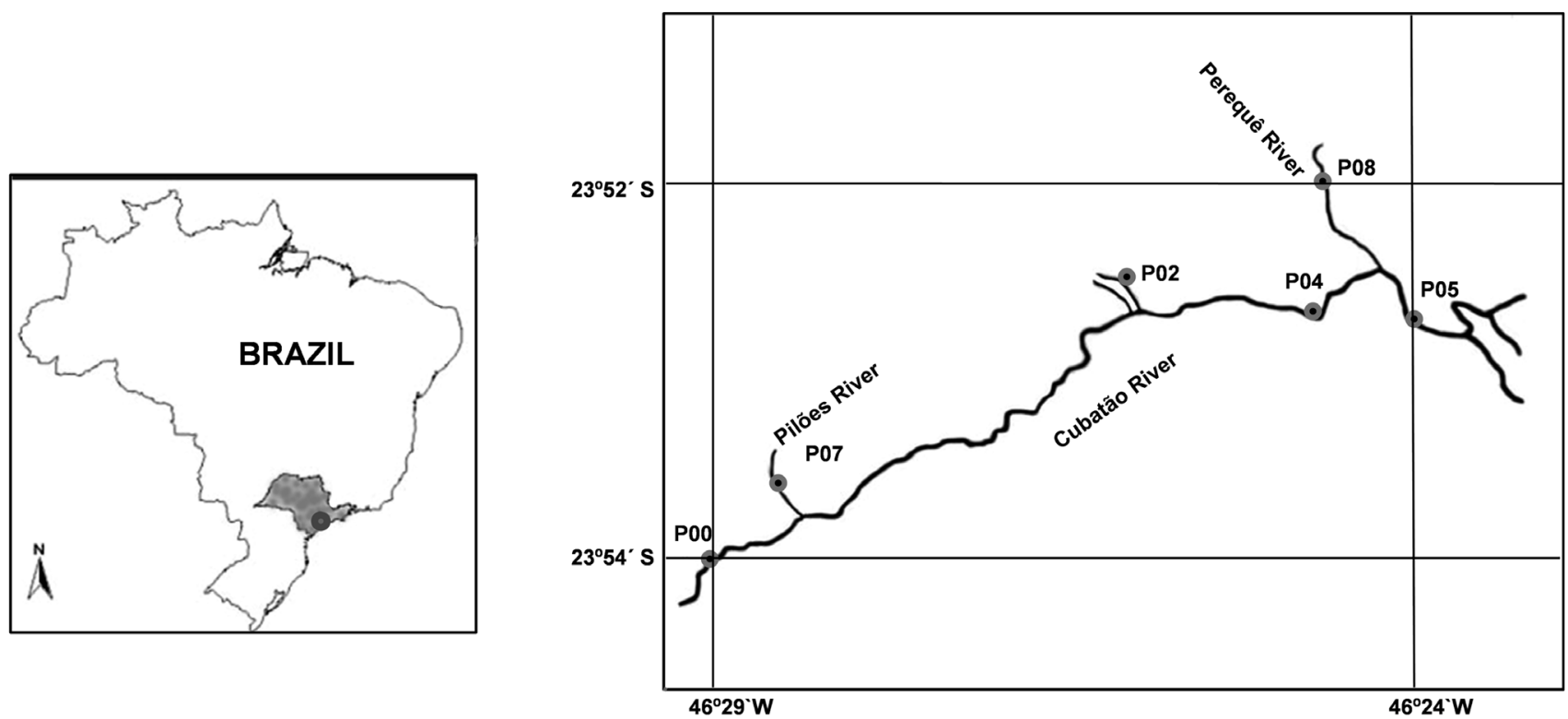

Figure 1. Geo-referred position of the sediment sampling sites at the Cubatão River Basin, São Paulo, Brazil. 
counting were made: the first one decaying after one week, the second one between 15-20 days. Gamma spectrometry was conducted using a Canberra gamma X hyperpure Ge detector and associated electronics, with a resolution of $0.88 \mathrm{keV}$ and $1.90 \mathrm{keV}$ for ${ }^{57} \mathrm{Co}(121.97 \mathrm{keV})$ and ${ }^{60} \mathrm{Co}(1332.49 \mathrm{keV})$, respectively. Larizatti et al. (2001) provided further details of the analytical methodology.

The elements As, Ba, Br, Co, Cr, Cs, Fe, Hf, Na, Rb, $\mathrm{Sb}, \mathrm{Sc}, \mathrm{Ta}, \mathrm{Th}, \mathrm{U}, \mathrm{Zn}$ were determined, as well as the rare earth elements $\mathrm{Ce}, \mathrm{Eu}, \mathrm{La}, \mathrm{Lu}, \mathrm{Nd}, \mathrm{Sm}, \mathrm{Tb}$ and $\mathrm{Yb}$. The uncertainties of the results were calculated by standard uncertainty propagation. Methodology validation was done by analyzing reference materials BEN (Basalt-IWG-GIT) and Soil 7 (IAEA). The corresponding standard deviations ranged from 1.1 to $8.2 \%$ and relative errors, from 3.3 to $10 \%$ for the elements analyzed by INAA, resulting in good precision and accuracy, respectively.

\section{Atomic Absorption Spectrometry (GF-AAS and CV-AAS)}

In this study, samples were digested by following a microwave-assisted method (SW-846-3051) prescribed by USEPA (2007) for sediments. About $0.5 \mathrm{~g}$ of the sediment (in duplicate) was weighed in Teflon tubes and $10 \mathrm{~mL}$ of $\mathrm{HNO}_{3}$ was added. After dissolution, the solution was filtered and the final volume was completed to $50 \mathrm{~mL}$, in a volumetric flask. Measurements were performed in duplicate, limited to a deviation $\leq 20 \%$ and the concentration values were obtained using an analytical calibration curve. A calibration blank and a reagent blank were also measured and their values had to be less than the detection limit (DL) of the method to assure the quality of reagents and methodological procedures, respectively. Measurements were conducted in a Perkin Elmer AANALYST 800 instrument. The precision and accuracy of the method were evaluated by checking the recovery (percentage) of the respective analytes present in Certified Reference Material SS-1 and SS-2 (contaminated soils from EnviroMAT ${ }^{\mathrm{TM}}$ ). Our results were within the confidence interval $(95 \%)$ of the certified reference materials. The mean concentration of $\mathrm{Cd}$ in the SS2 reference material was $2.07 \pm 0.08 \mathrm{mg} \mathrm{kg}^{-1}$, (2, consensus value); for $\mathrm{Pb}, \mathrm{SS} 1,121.3 \pm 2.5 \mathrm{mg} \mathrm{kg}^{-1}$ (Recovery $(\mathrm{R})=96.3 \%$ ), (126, consensus value, confidence interval: 116-136) and SS2, 219.4 $\pm 1.1 \mathrm{mg} \mathrm{kg}^{-1}(\mathrm{R}=94.2 \%)$, (233; consensus value, confidence interval- 219-247).

Total $\mathrm{Hg}$ determination in sediment samples was carried out by CV-AAS (in duplicate) by using the same solution digested for $\mathrm{Cd}$ and $\mathrm{Pb}$ determinations. Quality control was carried out by analyzing the certified reference materials Lake Sediment (BCR 280), Lake Sediment (IAEA, SL-1) and Marine Sediment reference material for trace metals and other constituents (MESS-3, NRCC). The results were consistent with certified values presenting pertinent errors and relative standard deviations less than $10 \%$. The mean concentrations of total $\mathrm{Hg}$ were $0.685 \pm 0.030 \mathrm{mg} \mathrm{kg}^{-1}$ for BCR $280(0.670$ $\left.\pm 0.019 \mathrm{mg} \mathrm{kg}^{-1}\right)(\mathrm{R}=102.2 \%) ; 0.135 \pm 0.005$ for IAEA-SL1 $\left(0.130 \mathrm{mg} \mathrm{kg}^{-1}\right)(\mathrm{R}=103.8 \%)$ and $0.082 \pm 0.007 \mathrm{mg} \mathrm{kg}^{-1}$ for MESS-3 $\left(0.091 \pm 0.09 \mathrm{mg} \mathrm{kg}^{-1}\right)(\mathrm{R}=90.1 \%)$.

\section{Contamination assessment by $\mathrm{EF}$ and IGeo indexes}

It is well known that metals originating from the same source generally group together in silt and clay fractions. If enrichment occurs, it can be observed by using a normalization procedure that offsets the variability in mineralogy and grain size data (Camargo et al. 1986; Larizatti et al., 2001). The enrichment factor (EF) is defined as the ratio between the concentrations of the element in question and a conservative element in the sample divided by the same ratio calculated with background reference values. In this case, the used references were the North American Shale Composite (NASC) values and the background sediment values obtained by Luiz-Silva et al. (2006). The elements of natural origin that are structurally combined with one or more mineral phases are considered conservative. The main assumption for the application of a geochemical normalization for conservative elements is the existence of a linear relationship between the normalized and other metals (Ndjigui et al., 2015, Astudillo et al., 2005, Kamaruzzaman et al., 2011). In this study, Sc was used as a normalizer (Mori et al., 1999; Kamaruzzaman et al., 2011) according to equation 1 :

$\mathrm{EF}=\left[\mathrm{C}_{\mathrm{n}} / \mathrm{C}_{\mathrm{Sc}}\right]$ sample $/\left[\mathrm{C}_{\mathrm{n}} / \mathrm{C}_{\mathrm{Sc}}\right]$ (background)

(equation 1), where $\mathrm{C}_{\mathrm{n}}$ is element concentration and $\mathrm{C}_{\mathrm{Sc}}$ is $\mathrm{Sc}$ concentration.

According to Zhang \& Liu, (2002), if $0.5<\mathrm{EF}<1.5$, the elemental concentration is probably entirely due to crustal or natural weathering origin; values above 1.5 indicate anthropogenic contribution. The higher the EF value, the more severe is the anthropogenic contribution.

Geoaccumulation Index (IGeo) (Gomes et al. 2009, Audry et al. 2004) was also calculated for the concentrations obtained by INAA, adopting the same reference values used for the EF calculations (NASC values). Equation 2 below was used for IGeo calculation:

Igeo $=\log _{2}\left(\frac{C_{a m}}{1.5 C_{r e f}}\right)$ (equation 2)

where $\mathrm{C}_{\text {sample }}$ is the concentration of the element of interest in the sample and $\mathrm{C}_{\text {ref }}$ the reference concentration of the element of interest.

The classification of the contamination levels from $I G e o$ values is: < 0 , basal level; from 0 to 1 , not polluted to moderately polluted; from 1 to 2 , moderately polluted; from 2 to 3 , moderately polluted to heavily polluted; from 3 to 4 , heavily polluted; from 4 to 5 , heavily to extremely polluted and $>5$, extremely polluted.

\section{Sediments Ecotoxicity}

Hyalella azteca amphipod was exposed to sediments for assessing the acute toxicity (growth and survival). The employed methodology followed the ABNT (2007) Brazilian standard method. Juvenile organisms were exposed to whole sediments (age 7 and 14 days) for 10 days. These tests were prepared in chambers with one part of sediment and 2 parts of water (1:2). 10 organisms were exposed for each 
replicate, totalizing 40 organisms exposed for each site and one negative control.

After 10 days, the surviving organisms were registered and mortality was observed. Statistical analyses were run by the use of the TOXSTAT software, version 3.5 (Gulley, 1996), based on the survival of the negative control. Bioequivalence constant $(\mathrm{B})$ for H.azteca $(\mathrm{B}=0.89)$ was used in the calculations (Bertoletti et al., 2007). Results were referred as "toxic" or "non-toxic".

Additionally, body growth analysis was carried out for the surviving $H$. azteca individuals, as a subletal response. This step followed the USEPA Standard guidelines (2000), using image measurements (Leica S8APO, coupled with the digital camera, Leica DFC280) computer for visualization of images and the specific software (IM 50) for body size analyzes (Figure 2).

\section{RESULTS AND DISCUSSION}

Granulometric composition of sediments and references for each site are given at Table 1. Most samples were classified as sandy ( $>80 \%$ of sand in composition). The composition of samples from P5 and P8 were slightly different: the percentages of clay + silt were higher than $20 \%: 29.2 \%$ and $22.0 \%$, respectively. Therefore, they can be classified as mostly silty sand.

Mean concentrations of metals and their respective standard deviations $\left(\mathrm{mg} \mathrm{kg}^{-1}\right)$ obtained by INAA are presented in Table 2 for the samples collected in August 2010 (dry season, $2^{\text {nd }}$ campaign), February 2011 (wet season, $3^{\text {rd }}$ campaign) and June 2011 (dry season, $4^{\text {th }}$ campaign). In general, there was a substantial variation between campaigns and sites for the most of analyzed elements. All data obtained by INAA are discussed below by means of Enrichment Factor (EF) and IGeo values.

Table 3 presents the EF results calculated for the INAA results and considering NASC values and the background (BG) values obtained for Luiz-Silva et al (2008) as regional reference values and $\mathrm{Sc}$ as a normalizer element. In the LuizSilva study, a sediment core from Morrão River (SantosCubatão Estuarine System) was analyzed and the elemental concentrations at $220-260 \mathrm{~cm}$ depth in the core were considered as representative of the background of the region. These values are presented in Table 2.

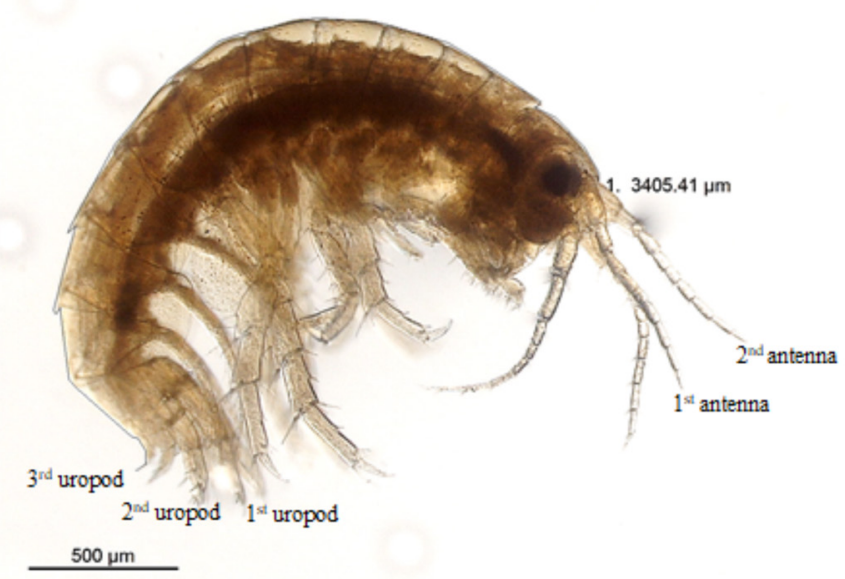

Figure. 2. Hyalella azteca - body size analysis: organism length $(\mu \mathrm{m})$ from the base of the $3^{\text {rd }}$ uropod to the base of the first antenna.

When NASC values were used for calculation, $\mathrm{EF}>2.0$ was obtained for many elements, in sediments from all sampling sites mainly for $\mathrm{As}, \mathrm{Br}, \mathrm{Hf}, \mathrm{Th}, \mathrm{U}$ and for all rare earth elements (REEs), at sites P00, P05, P07 and P08, with higher values in sediments from P05 (Table 3). However, when the BG regional values from Luiz-Silva et al (2008) were used, only $\mathrm{Ca}, \mathrm{Co}, \mathrm{Hf}, \mathrm{Rb}, \mathrm{Sb}$, Th and $\mathrm{U}$ presented an $\mathrm{EF}>1.5$, being $\mathrm{Hf}$ the element with higher values for all sampling sites, indicating a probable anthropogenic influence for this element. It is worth pointing out that there are no regional background values for all elements determined by INAA in the present study for comparison. The most contaminated sampling site is P5, which showed high enrichment in all campaigns. Sediments from P4 ( $2^{\text {nd }}$ campaign $)$, P7 ( $4^{\text {th }}$ campaign $)$ and P8 ( $2^{\text {nd }}$ campaign) were also heavily polluted. According to LuizSilva et al study (2008), the elements Hf, Th, U are strongly associated with fertilizer industry-derived $\mathrm{P}$ concentrations.

Silva et al. (2011) analyzed ten sediment core samples from Baixada Santista for metal and trace elements distribution by INAA. They showed EF $>1.5$ for light rare earth elements (LRE - La, Ce, Nd, Sm), Th, U, Zn and Hf, which is consistent with results obtained in the present study.

The IGeo index was also calculated for the INAA results by using the two reference values, NASC and Luiz-Silva

Table1. Granulometric composition of sediments collected during March/2010 and June/2011

\begin{tabular}{l|ccc}
\hline Reference of the sampling site & \multicolumn{2}{c}{ Sediment Granulometry (\%) } \\
\hline & $\begin{array}{c}\text { Sand } \\
(2-62 \mu \mathrm{m})\end{array}$ & $\begin{array}{c}\text { Silt } \\
(62 \mu \mathrm{m}-3.94 \mu \mathrm{m})\end{array}$ & $\begin{array}{c}\text { Clay } \\
(3.94 \mu \mathrm{m}-0.2 \mu \mathrm{m})\end{array}$ \\
\hline P0: Cubatão River - Ecological Park Itutinga Pilões & 94.4 & 5.5 & 0.1 \\
P02: near to water treatment station & 97.5 & 2.5 & 0 \\
P04: Ana Costa Hospital and downstream of CBE - Estireno & 88.6 & 10.4 & 1.0 \\
P05: Cubatão River - Carbocloro Chemical Industry & 70.8 & 26.1 & 3.1 \\
P07: Pilões River - Itutinga Pilões Park & 86.1 & 12.5 & 1.4 \\
P08: Perequê River - downstream Perequê Ecological Park & 78.0 & 19.4 & 2.6 \\
\hline
\end{tabular}




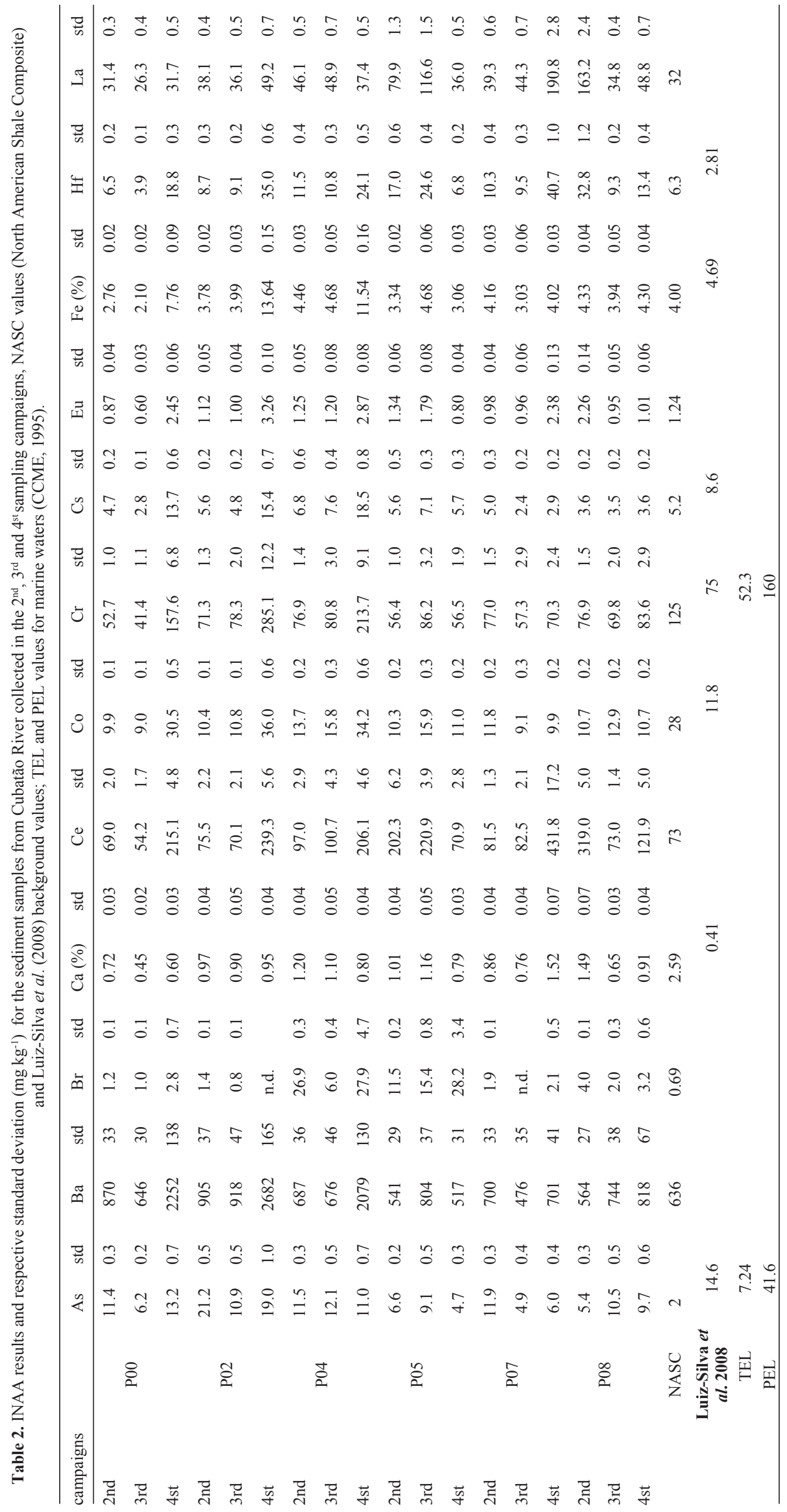




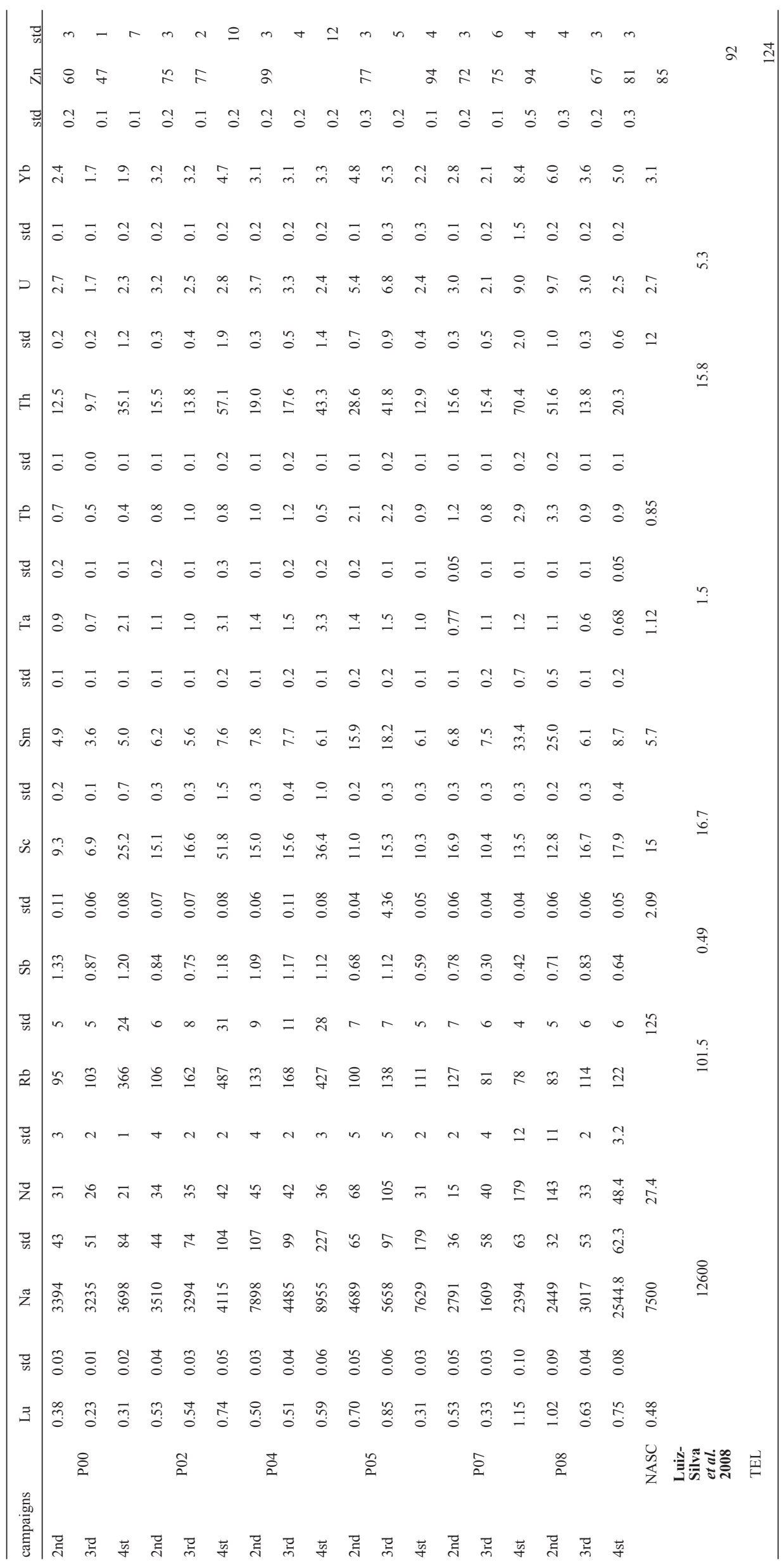


background regional values (Table 4). The IGeo calculated by using NASC as reference values showed $I G e o>1.0$ mainly for As and $\mathrm{Br}$, with higher values exhibited in sediments from P04 and $\mathrm{P} 05$. For the $I G e o$ values calculated by using $\mathrm{BG}$ regional values, mainly Hf showed $1.0<I G e o<3.0$, in all sampling sites, with the sediments being considered as moderated to polluted for this element. Sample site P05, in all campaigns, presented the higher values for $\mathrm{EF}$ and $I G e o$ is, and can be considered as the most contaminated to the elements analyzed by INAA.

From the results, it could be inferred that IGeo values (Table 4), in general, confirmed the EF results (Table 3), but they were more restrictive. In general, when BG regional values for metal and trace elements in sediments are available the $\mathrm{EF}$ and IGeo results are more reliable or realistic regarding the sediment contamination assessment.

The results obtained for As, $\mathrm{Cr}$ and $\mathrm{Zn}$ by INAA and metals $\mathrm{Cd}, \mathrm{Hg}$ and $\mathrm{Pb}$ by AAS (Table 2 and 5, respectively) were compared to the TEL and PEL sediment quality guidelines (SQGs) proposed by the Canadian Council of Ministers of the Environment (CCME) and adopted by CETESB (2016) for sediment quality criteria classification. TEL is the limit below which no adverse effects on the biological community is observed and PEL, the probable level of occurrence of adverse effects on the biological community. Only the samples from the $2^{\text {nd }}$ campaign were analyzed by AAS technique. For $\mathrm{Cd}$, all results obtained were below the TEL $\left(0.7 \mathrm{mg} \mathrm{kg}^{-1}\right)$, for all sampling sites. For $\mathrm{Pb}$, all the results were below the
TEL value, excepting at $\mathrm{P} 02\left(30.2 \mathrm{mg} \mathrm{kg}^{-1}\right)$. For $\mathrm{Hg}$, all the sediments presented $\mathrm{Hg}$ concentrations below the TEL $(0.13$ $\mathrm{mg} \mathrm{kg}^{-1}$ ).

For the $\mathrm{As}$ and $\mathrm{Cr}$ and $\mathrm{Zn}$, the comparison with TEL and PEL indicated that for As, the sediments from P00, P02 and P04 presented the higher values, exceeding the TEL (7.2 $\mathrm{mg} \mathrm{kg}^{-1}$ ), with $\mathrm{P} 02$ showing the highest values. For $\mathrm{Cr}$, the sediments from P00, P05, P07 and P08 showed values between TEL and PEL. The values at P02 and P04 exceeded PEL $\left(160 \mathrm{mg} \mathrm{kg}^{-1}\right)$. For $\mathrm{Zn}$, the sediments from P05, P07 and P08 presented values below TEL, while the samples from P00, P02 and P04 had concentrations above the TEL (124 mg $\left.\mathrm{kg}^{-1}\right)$. These facts suggest that $\mathrm{As}, \mathrm{Cr}$ and $\mathrm{Zn}$ are candidates for causing toxicity in all sediment tested, particularly in P0, P2 and P4 ( $4^{\text {th }}$ campaign).

Lamparelli et al. (2001) gathered information about the sources of heavy metals in Cubatão River. They related styrene production to $\mathrm{Cu}$, total $\mathrm{Cr}, \mathrm{Cr}^{+6}, \mathrm{Hg}$ and $\mathrm{Zn}$; oil refinery to $\mathrm{Cd}$, $\mathrm{Pb}, \mathrm{Cu}$, total $\mathrm{Cr}, \mathrm{Cr}^{+6}, \mathrm{Hg}, \mathrm{Ni}$ and $\mathrm{Zn}$; fertilizers to $\mathrm{As}, \mathrm{Pb}, \mathrm{Cu}$, total $\mathrm{Cr}, \mathrm{Cr}^{+6}, \mathrm{Mn}, \mathrm{Ni}$ and $\mathrm{Zn}$; cellulose to $\mathrm{Cd}, \mathrm{Cu}$, total $\mathrm{Cr}$, $\mathrm{Cr}^{+6}, \mathrm{Mn}, \mathrm{Hg}, \mathrm{Ni}$ and $\mathrm{Zn}$; and steel production to $\mathrm{As}, \mathrm{Cd}$, total $\mathrm{Cr}, \mathrm{Cr}^{+6}, \mathrm{Cu}, \mathrm{Hg}, \mathrm{Mn}, \mathrm{Ni}, \mathrm{Pb}$ and $\mathrm{Zn}$. These elements are used as raw material, consumable items or input during productive processes.

According to Luiz-Silva et al. (2008), Cr, Cd, Pb and $\mathrm{Zn}$ in the region are related to steel plant-derived $\mathrm{Fe}$ concentrations. Relevant amounts of $\mathrm{Zn}, \mathrm{Pb}$ and $\mathrm{Cr}$ were reported by Abessa

Table 4. IGeo values calculated for the INAA results by using NASC (North American Shale Composite) values and Luiz-Silva et al. (2008) as regional background reference values.

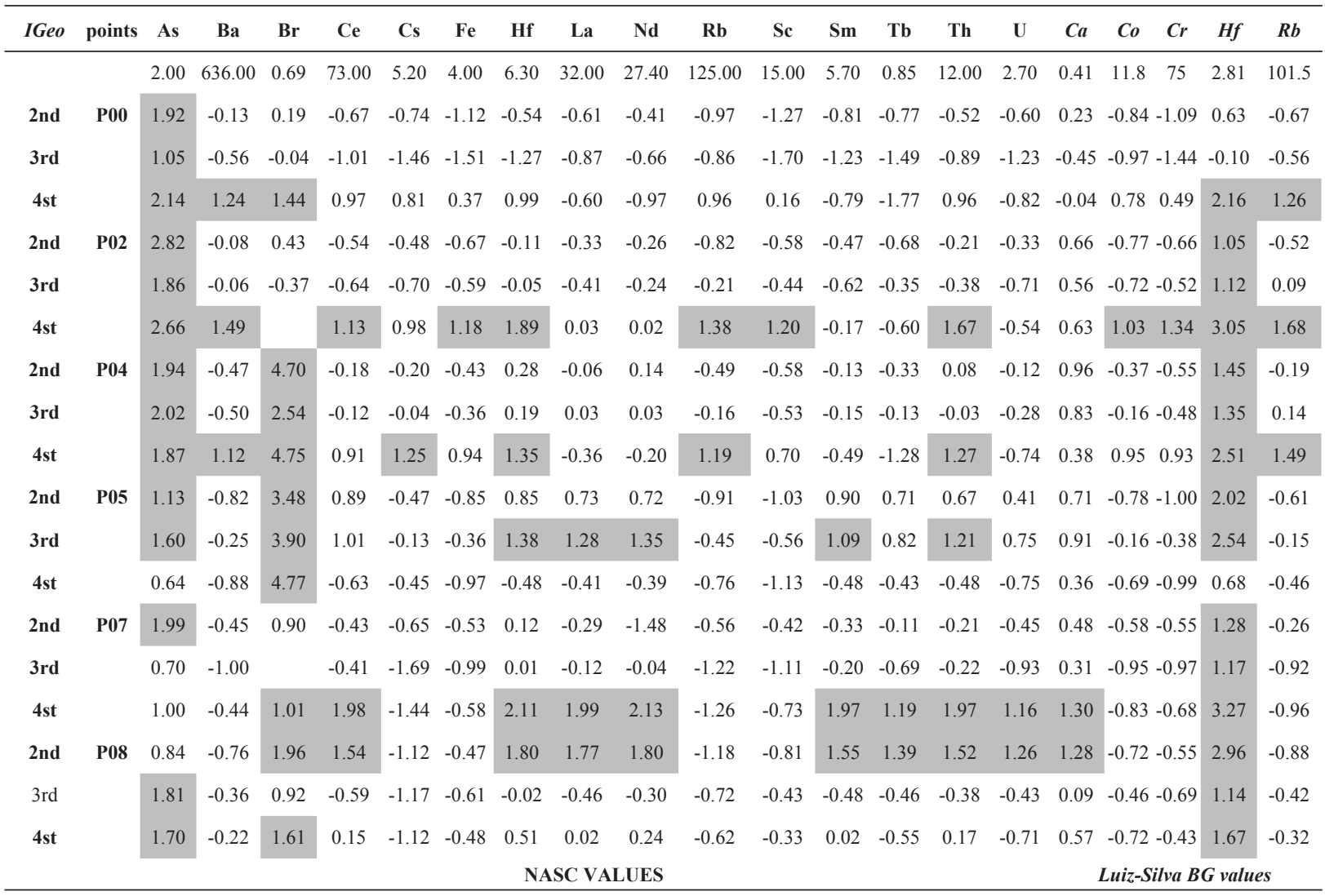


Table 5. Heavy metal concentrations obtained by AAS techniques in the sediment samples from Cubatão River $\left(\mu \mathrm{g} \mathrm{kg}^{-1}\right)$ and TEL and PEL values $\left(\mu \mathrm{g} \mathrm{kg}{ }^{-1}\right)$, for marine water (CCME, 1995).

\begin{tabular}{ccccccccccccccccc}
\hline & \multicolumn{1}{c}{ P0 } & \multicolumn{2}{c}{ P02 } & \multicolumn{2}{c}{ P04 } & \multicolumn{2}{c}{ P05 } & \multicolumn{2}{c}{ P07 } & \multicolumn{2}{c}{ P08 } & TEL & PEL \\
\hline & Conc & std & Conc & std & Conc & std & Conc & std & Conc & std & Conc & std & $\left(\mu \mathrm{kg}^{-1}\right)$ & $\left.(\mu \mathrm{g} \mathrm{kg})^{-1}\right)$ \\
$\mathbf{C d}^{*}$ & 52 & 2 & 69.8 & 0.009 & 94.2 & 2,3 & 107 & 1.5 & 97.2 & 4.4 & 85 & 1.3 & $\mathbf{7 0 0}$ & $\mathbf{4 2 1 0}$ \\
$\mathbf{P b}^{*}$ & 8,894 & 95 & 31,110 & 201 & 15,320 & 56 & 10,250 & 42 & 16,000 & 59 & 11,870 & 73 & $\mathbf{3 0 , 2 0 0}$ & $\mathbf{1 1 2 , 0 0 0}$ \\
$\mathbf{H g}^{*}$ & 23.0 & 0.1 & 68.2 & 0.8 & 70.0 & 0.4 & 62.7 & 0.7 & 72.2 & 0.6 & 30.0 & 0.6 & $\mathbf{1 3 0}$ & $\mathbf{6 9 6}$ \\
$\mathbf{H g}^{* *}$ & 40.4 & 0.2 & 41.0 & 0.2 & 71.4 & 0.2 & 98.6 & 0.8 & 21.3 & 0.3 & 24.27 & 0.06 & \\
\hline
\end{tabular}

$*=2^{\text {nd }}$ campaing (August $\left./ 2010\right) ; * * 3^{\text {rd }}$ campaign (February/2011); std - standard deviation

Table 6. Summary of polluting elements in high toxicity sites/campaigns. Parameters used to assess pollution for each element are also identified.

\begin{tabular}{|c|c|c|c|c|c|}
\hline & $\begin{array}{l}\text { P2 - 2nd } \\
\text { Campaign }\end{array}$ & $\begin{array}{l}\text { P4 - 2nd } \\
\text { Campaign }\end{array}$ & $\begin{array}{l}\text { P5 - 2nd } \\
\text { Campaign }\end{array}$ & $\begin{array}{l}\text { P5 - 4nd } \\
\text { Campaign }\end{array}$ & $\begin{array}{l}\text { Assessed } \\
\text { Parameters }\end{array}$ \\
\hline As & $\mathrm{EF} / I G e o / \mathrm{TEL}$ & $\mathrm{EF} / \mathrm{IGeo} / \mathrm{TEL}$ & $\mathrm{EF} / I G e o$ & $\mathrm{EF}$ & $\mathrm{EF} / I G e o / \mathrm{TEL}$ \\
\hline $\mathrm{Br}$ & $\mathrm{EF}$ & $\mathrm{EF} / \mathrm{IGeo}$ & $\mathrm{EF} / I G e o$ & $\mathrm{EF} / I G e o$ & $\mathrm{EF} / I G e o$ \\
\hline $\mathrm{Ca}$ & $\mathrm{EF}$ & $\mathrm{EF}$ & $\mathrm{EF}$ & $\mathrm{EF}$ & $\mathrm{EF} / \mathrm{IGeo}$ \\
\hline $\mathrm{Cr}$ & TEL & TEL & TEL & TEL & TEL \\
\hline $\mathrm{Hf}$ & $\mathrm{EF} / I G e o$ & $\mathrm{EF} / \mathrm{IGeo}$ & $\mathrm{EF} / I G e o$ & $\mathrm{EF}$ & $\mathrm{EF} / \mathrm{IGeo}$ \\
\hline $\mathrm{Pb}$ & TEL & None & None & N.A.* & TEL \\
\hline $\mathrm{Sb}$ & $\mathrm{EF}$ & $\mathrm{EF}$ & $\mathrm{EF}$ & $\mathrm{EF}$ & $\mathrm{EF}$ \\
\hline $\mathrm{Zn}$ & None & TEL & TEL & TEL & TEL \\
\hline Mortality (\%) & 55.0 & 0 & 57.5 & 82.5 & - \\
\hline Growth $(\mu \mathrm{m})$ & 2744.22 & 2027.24 & 2278.93 & 2614.35 & - \\
\hline
\end{tabular}

$* \mathrm{~Pb}$ concentration was not measured in the $4^{\text {th }}$ campaign.

et al. (2008) in sediments from Santos Estuarine System. Those results exceeded TEL and PEL in different sites. They obtained similar data for $\mathrm{Hg}$, which highest concentrations were detected in sediments from the inner portion of the estuary. In the present study, the concentrations of $\mathrm{Cr}$, $\mathrm{U}$ and $\mathrm{Zn}$ were of the same order of magnitude, but much higher for As, Hf and Th of those of the Luiz-Silva and Abessa studies.

This study also corroborates the findings obtained by other authors on the mercury distribution and concentrations in sediments from the SES (Siqueira et al., 2005; Luiz-Silva et al., 2006; Gomes et al., 2009). The highest concentrations are associated with the vicinity of the industrial sector and end up contributing to contamination of Santos-São Vicente estuary through waters from the Cubatão River Basin.

Silva et al (2006) collected 5 bottom sediment samples along the Cubatão River to determine concentration of $U$ and Th natural radionuclide series and some metals $(\mathrm{Al}, \mathrm{Ca}, \mathrm{Cr}$, $\mathrm{Cu}, \mathrm{Hg}, \mathrm{Li}, \mathrm{Ni}, \mathrm{Pb}, \mathrm{Mg}, \mathrm{Mn}, \mathrm{Zn})$. The concentration ranges of these metals were $\mathrm{Cr}\left(56-72 \mathrm{mg} \mathrm{kg}^{-1}\right), \mathrm{Zn}\left(94-131 \mathrm{mg} \mathrm{kg}^{-1}\right)$, $\mathrm{Pb}\left(23-34 \mathrm{mg} \mathrm{kg}^{-1}\right)$ and $\mathrm{Hg}\left(71-143 \mu \mathrm{g} \mathrm{kg}^{-1}\right)$. In our study, the concentrations found for P02 and P04 (near the sampling sites of the Silva study), $2^{\text {nd }}$ and $3^{\text {rd }}$ campaigns, were: $\mathrm{Cr}$ (71-81 $\left.\mathrm{mg} \mathrm{kg}{ }^{-1}\right), \mathrm{Zn}\left(75-105 \mathrm{mg} \mathrm{kg}^{-1}\right), \mathrm{Pb}\left(15.3-31.1 \mathrm{mg} \mathrm{kg}^{-1}\right)$ and $\mathrm{Hg}$ (63-68 $\left.\mu \mathrm{g} \mathrm{kg}^{-1}\right)$. The concentrations found in the present study were very similar to those of Luiz-Silva study (2006).

In conclusion, when TEL and PEL were used for sediment quality classification, P02 and P04 presented the worst situation, mainly for $\mathrm{Cr}, \mathrm{Pb}$, As and $\mathrm{Zn}$, with $\mathrm{Cr}$ concentrations exceeding the PEL. When EF and IGeo indexes were used, P05 presented the highest contamination values for $\mathrm{Br}, \mathrm{Hf}, \mathrm{Th}, \mathrm{U}$ and rare earth elements (REEs). A widespread contamination by As, $\mathrm{Cr}$, $\mathrm{Hf}$ and $\mathrm{Zn}$ was detected. $\mathrm{Cr}$ and $\mathrm{Zn}$ concentrations were particularly high in sediments from P0, P02 and P04 (4 $4^{\text {th }}$ campaign). There is also $\mathrm{Br}$ contamination localized mainly in sediments from P04, P05 and P08.

\section{Ecotoxicity}

The results of the acute toxicity with $H$. azteca as well as the growth of organisms were presented in the figures 3 and 4. Toxicity of whole sediments was noticed during the $2^{\text {nd }}$ campaign in $\mathrm{P} 2$ and $\mathrm{P} 5$ (55\% and $57.5 \%$ mortality, respectively), and in P5 during the $4^{\text {th }}$ campaign ( $82.5 \%$ mortality). Lower toxicity values were obtained in other sites. At P0, for instance, mortality was $<20 \%$; at $\mathrm{P} 4,<25 \%$. At $\mathrm{P} 0$ and $\mathrm{P} 8$, mortality was $<40 \%$. The results obtained to $\mathrm{P} 7$ and $\mathrm{P} 8$ are concerning, because both sites are located within a protected area (Serra do Mar State Park, nucleus Itutinga Pilões), i. e., in supposedly more preserved regions when compared to the other sites. Body size analysis showed unpaired growth of $H$. azteca in sediments from many campaigns/sites. Animals from $\mathrm{P} 4$ in the $2^{\text {nd }}$ campaign presented particularly lower body sizes, $2027.24 \mu \mathrm{m}$. It is interesting to notice that $\mathrm{Cr}$ and $\mathrm{Zn}$ above PEL concentrations in $4^{\text {th }}$ campaign of $\mathrm{P} 2$ and $\mathrm{P} 4$ did not culminate in high toxicity.

Regarding toxicity data from other studies, indicative of toxicity was obtained during measurements carried out at water sample of Cubatão River (Garcia et al., 2017). 


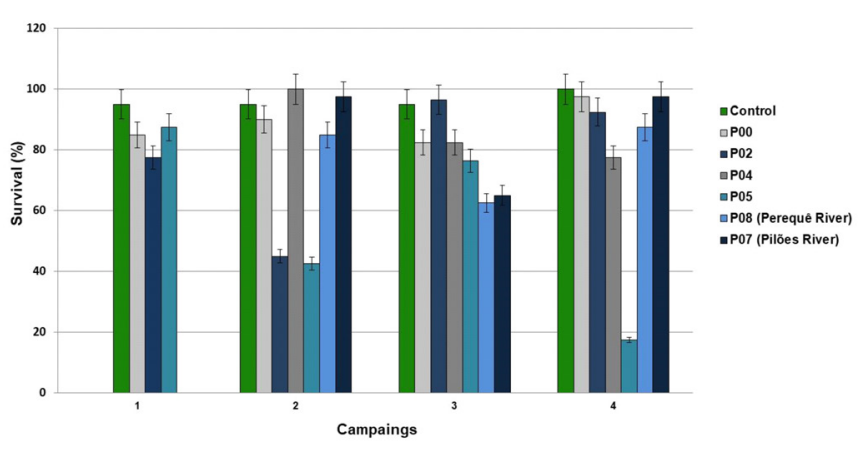

Figure 3. Survival of Hyalella azteca exposed to sediments of the Cubatão River and its tributaries for ten days.

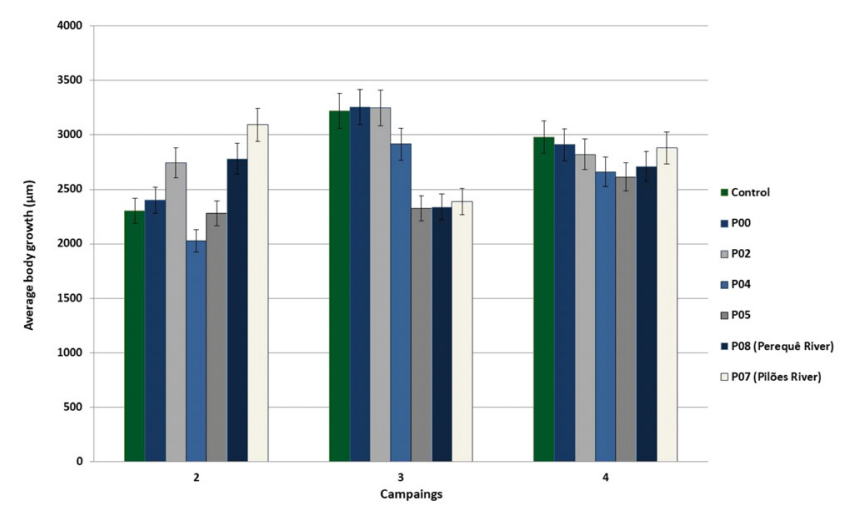

Figure 4. Average body growth of Hyalella azteca exposed to sediments from the Cubtão River and its tributaties for ten days.

There are four campaign/site results showing sediments with high toxicity levels: P2 ( $2^{\text {nd }}$ campaign $)$ and P5 ( $2^{\text {nd }}$ and $4^{\text {th }}$ campaigns $)$ presented mortality rates above $50 \% ; \mathrm{P} 4\left(2^{\text {nd }}\right.$ campaign) presented animals with very low body growth. Figures 5 and 6 contain all EF and Igeo results of these campaign/sites, in order to investigate further which elements may contribute to toxicity. Figure 5 shows clearly moderate enrichment levels of $\mathrm{Ca}$, $\mathrm{Hf}$ and $\mathrm{Sb}$ regarding Luiz-Silva's values. Note that $\mathrm{Hf}$ is not as high when NASC is used as reference. P2 ( $2^{\text {nd }}$ campaign) has significant As enrichment. $\mathrm{Br}$ is very high at $\mathrm{P} 4$ and $\mathrm{P} 5$ in the $2^{\text {nd }}$ campaign, and it is extremely high in $4^{\text {th }}$ campaign of P5. One flagrant fact is the high overall moderate enrichment at $\mathrm{P} 5,2^{\text {nd }}$ campaign.

Cubatão River Basin was also studied to correlate epidemiologic data and human exposures to environmental contaminants (indicators). Bioaccumulation determinations demonstrated metals in vegetation: $\mathrm{Zn}>\mathrm{Pb}>\mathrm{Cr}>\mathrm{Cu}>\mathrm{Cd}$ (Ferreira Braga, 2009). Comparing our results to FerreiraBraga's, we also detected high levels of $\mathrm{Zn}$ and $\mathrm{Cr}$. $\mathrm{Pb}$ was high only in P2 ( $2^{\text {nd }}$ campaign). Cd was not found in concerning amounts.

Figure 6 separates more clearly which elements contribute to pollution in the higher toxicity sites/campaigns. Again, in P2 we see predominant contamination by As, together with some contribution from Hf. In the $2^{\text {nd }}$ campaign, P4 and P5, as well as the in $4^{\text {th }}$ campaign of $\mathrm{P} 5$, indisputably show $\mathrm{Br}$ as the main contaminant. Some contribution from As and Hf was also present in the $2^{\text {nd }}$ campaign, for $\mathrm{P} 4$ and $\mathrm{P} 5$.

One must not forget that not all elements measured by INAA and AAS had their EF and Igeo calculated due to absence of reference values. For instance, $\mathrm{Cr}, \mathrm{Pb}$ and $\mathrm{Zn}$ were assessed only by comparison with TEL and PEL. Then, Table 6 was built in order to summarize which elements are polluting the high toxicity sites/campaigns, and which parameters (EF, $I G e o$ or TEL) indicate pollution. Note that none of these elements exceeded PEL oriented value, excepted $\mathrm{Cr}$, in the high toxicity sites/campaigns.

Spearman's correlation coefficient between concentration and toxicity was calculated for all samples. Results are between \pm 0.4 . Such correlations lack statistical significance due to the size of our dataset. However, there is one notable exception: correlation between $\mathrm{Br}$ and body growth is -0.60 . This value passes the $\mathrm{P}<0.02$ statistical significance test. Therefore, $\mathrm{Br}$ is the only element numerically related (mathematically) to toxicity and, more specifically, to the underdevelopment of Hyalella azteca. All the other polluting elements (As, $\mathrm{Cr}, \mathrm{Hf}, \mathrm{Pb}, \mathrm{Sb}$ and $\mathrm{Zn}$ ) can only be identified as "possible contributors to toxicity".

It should be pointed out the influence of a wide list of chemicals that reached the Cubatão basin and their speciation and bioavailability (in the case of metals), $\mathrm{pH}$ and hardness of water influence during toxicity assessment, among some other natural interference (Rand, 1995).

\section{CONCLUSION}

There are many sources of contamination to the Cubatão River and the Santos Estuarine System, as previously discussed. INAA and AAS measurements together with EF and IGeo calculations revealed that metal concentrations can vary from low to extreme anthropogenic interference, depending on the element. More specifically, $\mathrm{As}, \mathrm{Br}, \mathrm{Cr}, \mathrm{Hf}$, $\mathrm{Pb}, \mathrm{Sb}$ and $\mathrm{Zn}$ were found in concerning amounts, especially As, $\mathrm{Br}, \mathrm{Cr}$ and $\mathrm{Zn}$. Ecotoxicity to H. azteca showed four sites/campaigns with particularly high toxicity levels in two different ways: $\mathrm{P} 2$ and $\mathrm{P} 5$ in the $2^{\text {nd }}$ campaign as well as $\mathrm{P} 5$ in the $4^{\text {th }}$ campaign showed mortality rates higher than $50 \%$; P5 in the $4^{\text {th }}$ campaign presented the highest toxicities. Animals from the $\mathrm{P} 4$ in the $2^{\text {nd }}$ campaign showed important underdevelopment of $H$. azteca individuals. Statistical significant negative correlation between $\mathrm{Br}$ concentration and body growth was detected.

\section{ACKNOWLEDGMENT}

The authors thank CNPq and FUNDESPA for research support.

\section{REFERENCES}

ABESSA, D.M.S., CARR, R.S., SOUSA, E.C.P.M., RACHID, B.R.F., ZARONI, L.P., GASPARRO, M.R., PINTO, Y.A., 

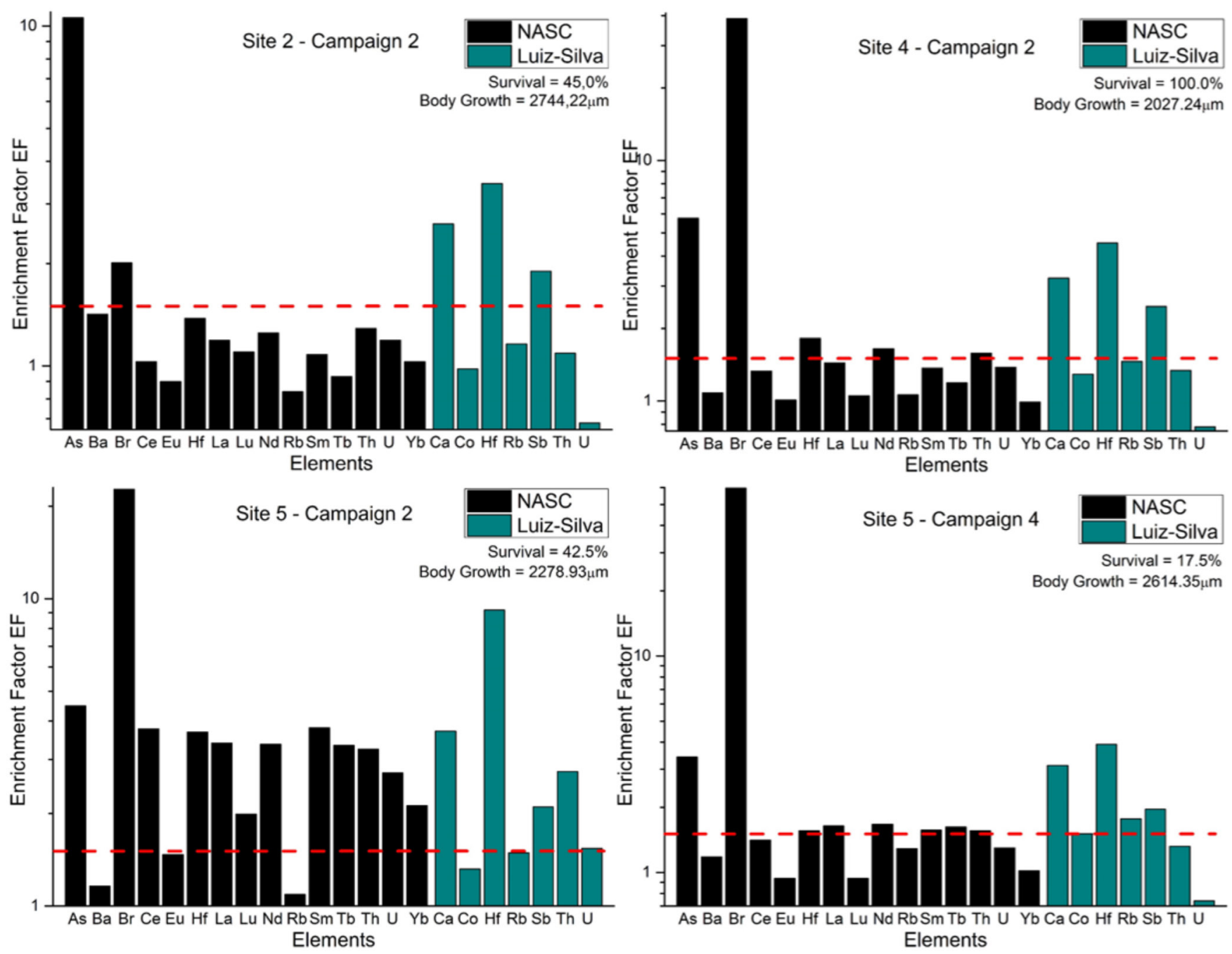

Figure 5. EF results of high toxicity sites. The red line indicates the limit above which anthropogenic contribution can be inferred. Using Luiz-Silva's results as reference, $\mathrm{Ca}, \mathrm{Hf}$ and $\mathrm{Sb}$ are systematically in moderate enrichment levels. The exception is $\mathrm{Hf}$ in $\mathrm{P} 5,2^{\text {nd }}$ campaign, which can be considered significantly enriched. EFs of As and $\mathrm{Br}$ indicate significant and very high enrichment, depending on the campaign/site.

BICEGO, M.C., HORTEKKANI, M.A., SARKIS, J.E. \& MUNIZ, P. 2008. Integrative ecotoxicological assessment of contaminated sediments in a complex tropical estuarine system. In: Marine Pollution: New Research. Tobias N. Hofer (Ed.). Chapter 4. Nova Science Publishers, Inc. ISBN: 978-1-60456-242-2.

ASSOCIAÇÃO BRASILEIRA DE NORMAS TÉCNICAS. ABNT. NBR 15470. 2007. Ecotoxicologia aquática - Toxicidade aguda e crônica - Método de ensaio com Hyalella spp. (Amphipoda) em sedimentos.

ASTUDILLO, L.R., YEN, I.C. \& BEKELE, I. 2005. Heavy metals in sediments, mussels and oysters from Trinidad and Venezuela. Rev. Biol. Trop., 53: 41-53.

AUDRY, S., SCHAFER, J., BLANC, G. \& JOUANNEAU, J. M. 2004. Fifty-year sedimentary record of heavy metal pollution $(\mathrm{Cd}$, $\mathrm{Zn}, \mathrm{Cu}, \mathrm{Pb}$ ) in the Lot River reservoirs (France). Environ. Pollut., 132: 413-26. http://doi.org/10.1016/j.envpol.2004.05.025

BERTOLETTI, E., BURATINI, S.V., PROSPÉRI, V.A., ARAÚJO, R.P.A. \& WERNER, L.I. 2007. Selection of Relevant Effect Levels for Using Bioequivalence Hypothesis Testing. J. Braz. Soc. Ecotoxicol., 2(2): 139-145.

CAMARGO, A.O., MONIZ, A.C, JORGE, J.A. \& VALADARES, J.M.A.S. 1986. Métodos de análise química e física de solos do IAC. Boletim Técnico, 106, Campinas, IAC, 94p.
CANADIAN COUNCIL OF MINISTERS OF THE ENVIRONMENT, CCME. 1999. Canadian environmental quality guidelines. Canadian protocol for the derivation of Canadian sediment quality guidelines for the protection of aquatic life.

COMPANHIA DE TECNOLOGIA DE SANEAMENTO AMBIENTAL. CETESB. 2015. Relatório de Qualidade das Águas Interiores no Estado de São Paulo. São Paulo.

FERREIRA-BRAGA, A.L. 2009. Estudo Epidemiológico na População Residente na Baixada Santista - Estuário de Santos: Avaliação de Indicadores de Efeito e de Exposição a Contaminantes Ambientais (Relatório técnico: PROJETO ESTUÁRIO CNPq 2005/40266351).

GARCIA, V.S.G., MATSUSHITA, E.T.D., MESQUITA, L.C.A., FÁVARO, D.I.T. \& BORRELY, S.I. 2017. Water quality and ecotoxicity assessment in surface waters from Cubatão River and Surroundings, São Paulo, Brazil. J. Water Resource Prot., 9: 1510-1525. http://doi.org/10.4236/jwarp.2017.912096

GOMES, V.P.; AMARAL, C.; JÚNIOR, L.C.G.N.; CÉSAR, A. \& ABESSA, D.M.S. 2009. Avaliação da contaminação por mercúrio nos sedimentos do estuário de Santos-SP, Brasil. Rev. Ceciliana, 1(2): 29-33.

GOMES, F.C., GODOY, J.M., GODOY, M.L.D.P., CARVALHO, 

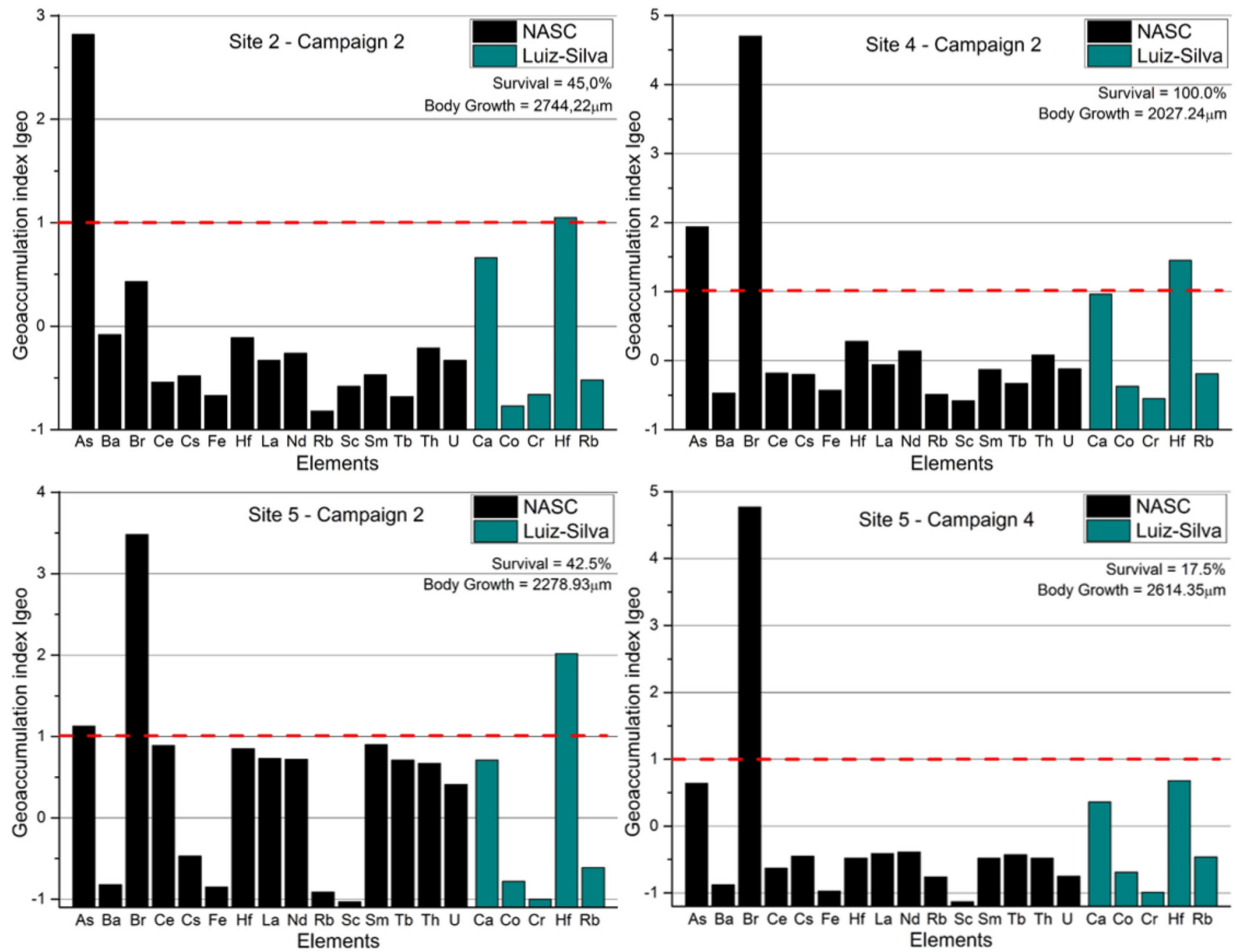

Figure 6. IGeo results of high toxicity sites. The red line indicates the limit above which anthropogenic contribution is inferred. IGeo results restate As and $\mathrm{Br}$ contamination. As values reached heavy contamination levels, while Br levels go as far as heavy to extreme contamination.

Z.L., LOPES, R.T.; SANCHEZ-CABEZA, J.A., LACERDA, L.D. \& WASSERMAN, J.C. 2009. Metal concentrations, fluxes, inventories and chronologies in sediments from Sepetiba and Ribeira Bays: A comparative study. Marine Pollut. Bull., 59: 123-133. https://doi.org/10.1016/j.marpolbul.2009.03.015

GULLEY, D. 1996. Toxstat 3.5. West Inc. University of Wyoming. Cheyenne, Wyoming.

KAMARUZZAMAN, B.Y., RINA, Z., JOHN, A.B. \& JALAL, K.C.A. 2011. Heavy Metals Accumulation in Commercially Important Fishes of South West Malaysian Coast. Res. J. Environ. Sci., 5 (6): 595-602. http://doi.org/10.3923/rjes.2011.595.602

LAMPARELLI, M.L, COSTA, M.P., PRÓSPERI, V.A., BEVILÁCQUA, J.E., ARAÚJO, R.P.A., EYSINK, G.G.L. \& POMPÉIA, S. 2001. Sistema Estuarino de Santos e São Vicente. Relatório Técnico CETESB. São Paulo.

LARIZATTI, F.E., FAVARO, D.I.T., MOREIRA, S.R.D., MAZZILLI, B.P. \& PIOVANO, E.L. 2001. Multielemental Determination by Instrumental Neutron Activation Analysis and Recent Sedimentation Rates Using $210 \mathrm{~Pb}$ Dating Method at Laguna del Plata, Cordoba, Argentina. J. Radioanal. Nucl. Chem., 249(1): 263-268. http://doi.org/10.1023/A:1013271316393

LUIZ-SILVA, W., MATOS, R.H.R., KRISTOCH, G.C. \& MACHADO, W. 2006. Variabilidade espacial e sazonal da concentração de elementos-traço em sedimentos do sistema estuarino Santos-Cubatão. Quím. Nova, 29(2): 256-263. http:// dx.doi.org/10.1590/S0100-40422006000200016

LUIZ-SILVA, W., MACHADO, W. \& MATOS, R.H.R. 2008. Multi-elemental contamination and historic record in sediments from the Santos-Cubatão Estuarine System, Brazil. J. Braz. Chem. Soc., 19(8):1490-1500. http://dx.doi.org/10.1590/ S0103-50532008000800008

MACHADO, W., LUIZ-SILVA, W., SANDERS, C.J. \& PATCHINEELAM, S.R. 2008. Coupled anthropogenic anomalies of radionuclides and major elements in estuarine sediments. Journal of Environ. Radioactivity, 99: 1329-1334. http://doi.org/10.1016/j.jenvrad.2008.04.006

MORI, P.E., REEVES, S., CORREIA, C.T. \&HAUKKA, M. 1999. Development of a fused glass disc XRF facility and comparison with the pressed powder pellet technique at Instituto de Geociências, São Paulo University. Rev. Bras. Geoc., 29(3): 441-446.

NDJIGUI, P.D., ABENG, S.A.E., EKOMANE, E., NZEUKOU, A.N., MANDENG, F.S.N. \& LINDJECK, M.M. 2015. Mineralogy and geochemistry of pseudogley soils and recent alluvial clastic sediments in the Ngog-Lituba region, Southern Cameroon: An implication to their Genesis. J. of African Earth Sci., 108: 1-14. http://doi.org/10.1016/j.jafrearsci.2015.03.023 RAND, G.M. 1995. Fundamentals of aquatic toxicology: effects, 
environmental fate, and risk assessment. Washington DC, Taylor and Francis.

SILVA, P.S.C., DAMATTO, S.R., MALDONADO, C., FÁVARO, D.I.T. \& MAZZILLI, B.P. 2011. Metal distribution in sediment cores from São Paulo State Coast, Brazil. Mar. Pollut. Bull., 62: 1130-1139. http://doi.org/10.1016/j.marpolbul.2011.02.046

SILVA, P.S.C., MAZZILLI, B.P., \& FÁVARO, D.I.T. 2006. Distribution of radionuclides and elements in Cubatão River sediments. J. Radioanal. Nucl. Chem., 269(3): 767-771. http:// doi.org/10.1007/s10967-006-0258-7

SIQUEIRA, G.W., BRAGA, E.S., PEREIRA, S.F.P. \& SILVA, E. 2005. Distribuição do mercúrio em sedimentos de fundo no Estuário de Santos - SP/Brasil. Esc. Minas, Ouro Preto, 50(4): 309-316. http://dx.doi.org/10.1590/S0370-44672005000400004

TERRA, B.F, ARAUJO, F.G., CALZA, C.F., LOPES, R.T. \& TEIXEIRA, T.P. 2007. Heavy metal in tissues of three fish species from different trophic levels in a tropical Brazilian river.
Water Air Soil Pollut., 187: 275-284. http://doi.org/10.1007/ s11270-007-9515-9

UNITED STATES ENVIRONMENTAL PROTECTION AGENCY. USEPA. 2007. SW-846 3051a: Microwave assisted acid digestion of sediments, sludges, soils and oils, Revision 1. U.S.: USEPA. https://www.epa.gov/sites/production/files/2015-12/ documents/3051a.pdf. Accessed in Sept 2017.

UNITED STATES ENVIRONMENTAL PROTECTION AGENCY. USEPA. 2000. Methods for Measuring the Toxicity and Bioaccumulation of Sediment-associated Contaminants with Freshwater Invertebrates. 2. Ed. Environmental Protection Agency, Washington, DC. EPA- 600/R-99/064.

ZHANG, J. \& LIU, C. L. 2002. Riverine Composition and Estuarine Geochemistry of Particulate Metals in China - Weathering Features, Anthropogenic Impact and Chemical Fluxes. Estuarine, Coastal and Shelf Science, 54: 1051-1070. http://doi. org/10.1006/ecss.2001.0879 